\title{
Market Performance and Corporate Governance in Banking Sector Indonesia Stock Exchange
}

\author{
Dwi Fitri Amelia \\ Student Master of Management, Faculty of Economics, Sriwijaya University, Indonesia \\ Corresponding author email: dwiamalia20@gmail.com \\ Mohamad Adam \\ Lecturer Master of Management, Faculty of Economics, Sriwijaya University, Indonesia \\ Email:mr_adam2406@yahoo.com \\ Isnurhadi \\ Lecturer Master of Management, Faculty of Economics, Sriwijaya University, Indonesia \\ Email: isnurhadi2013@gmail.com \\ Marlina Widiyanti \\ Lecturer Master of Management, Faculty of Economics, Sriwijaya University, Indonesia \\ Email: marlinawidiyanti68@yahoo.co.id
}

\begin{abstract}
This research aimed to determine the effect of market performance and corporate governance on the banking sector listed on the Indonesia Stock Exchange (IDX). The sample used as many as 20 companies during the 2015-2019 period using a purposive sampling technique. The data analysis technique used is linear regression analysis. The results obtained from the research are that Earnings per Share and Price Earnings Ratio influences stock returns in the banking sector and Good Corporate Governance can moderate Earnings per Share and Price Earnings Ratio on stock returns.
\end{abstract}

Keywords---earnings per share, good corporate, good governance, price-earnings ratio, stock return.

\section{Introduction}

Investment activities in the capital market are activities to place funds in one or more assets during a specific period to obtain income or increase funds on the initial investment value, aiming to maximize the expected return. Getting a profit (return) is the main objective of investors' trading activities in the capital market. Stock return is a factor that affects investors' interest in investing in a company with a high rate of return given by the company to investors, indicating that the company has an excellent corporate performance. Hence, investors believe that the company will positively affect shares invested by investors in the capital market (Pratomo, 2001; Hadianto \& Wijaya, 2010; Yamato et al., 2017; Sang et al., 2020). The company's performance is good or bad; it can be seen from the financial ratio of Earning per Share (EPS) and Price-earnings Ratio. Earnings per Share is a ratio that shows how much profit (return) investors get for each Share (Rahman \& Shamsuddin, 2019; Houmes \& Chira, 2015). EPS shows that the greater the profit of each Share for the owner, it will affect its stock return in the capital market. Price Earnings Ratio can provide investors with information about its past performance and prospects in the future. Based on studies, the authors found a research gap in these different results. Farkhan \& Ika (2012) indicate this, et al. In their research show that the Debt to Equity Ratio does not have a significant effect on stock returns, while the Price Earnings Ratio has a significant effect on stock returns. Arista \& Astohar (2012) found that Price to Book Value has a significant effect on stock returns, while Earnings per Share has no significant effect on stock returns. The previous research results made the author want to do research on the influence of market performance and corporate governance in the 
banking sector listed on the Indonesia Stock Exchange.

\section{Method}

Secondary data is obtained indirectly or through intermediaries from various sources and is available in various media. The data source is obtained from the Indonesia Stock Exchange website. This research population is companies in the banking sector listed on the Indonesia Stock Exchange. The samples obtained were 20 companies and used a sampling technique, namely, purposive sampling. Independent variable, the independent variable in this study is the market ratio measured using Earning Per Share and Price-earnings Ratio.

$$
\begin{aligned}
\mathrm{EPS}= & \text { net } \text { income } \text { after interest and taxes } \\
& \text { the number of shares outstanding } \\
\mathrm{PER}= & \text { stock price } \\
& \text { Profit per Share }
\end{aligned}
$$

The dependent variable, the dependent variable in this study is stock returns.

This study's moderating variable is that good corporate governance is measured by transparency, accountability, responsibility, independence, and fairness

\section{Data analysis technique}

Descriptive statistical analysis provides an overview or description of the data seen from the value (mean), standard deviation, variance, maximum, minimum, sum, range, kurtosis, and slope of the distribution (weakness). Aronow et al. (2011), explains that descriptive analysis provides an overview of the data presented in the study. Multiple Linear Regression Analysis Multiple regression analysis is performed to analyze the influence of Earnings per Share (EPS) and Price Earnings Ratio (PER), Good Corporate Governance (GCG) on stock returns in the banking sector.

$$
\mathrm{Y}=\alpha+\mathrm{b} 1 \mathrm{X} 1+\mathrm{b} 2 \mathrm{X} 2+\mathrm{b} 3 \mathrm{X} 3+\mathrm{e}
$$

Analysis of the Moderator Regression test to test the relationship between the moderating and criterion variables and the predictor with the regression equation. Here is the equation.

$$
\begin{aligned}
& Y i=\alpha+\beta 1 X 1+\beta 2 X 2+\varepsilon \\
& Y i=\alpha+\beta 1 X 1+\beta 2 X 2+\beta 3 Z 1+\varepsilon \\
& Y i=\alpha+\beta 1 X 1+\beta 2 X 2+\beta 3 Z 1+\beta 4 X 1 * Z 1+\beta 5 X 2 * Z 1+\varepsilon
\end{aligned}
$$

\section{Result}

Table 1

Descriptive analysis results

\begin{tabular}{lrrrrr}
\hline & N & Minimum & Maximum & \multicolumn{1}{c}{ Mean } & Std. Deviation \\
\hline EPS & 20 & -485.000 & 1.071 .510 & 164.1721 & 255.7385 \\
PER & 20 & -101.9259 & 822.1584 & 24.56716 & 93.99966 \\
GCG & 20 & 17.508 & 67.701 & 34.750 & 229.017 \\
Return Saham & 20 & 67.3168 & 14057.38 & 2136.662 & 3065.551 \\
Valid N (listwise) & 20 & 7 & & & \\
\hline
\end{tabular}

Source: The Primary Data Processed, 2020 
Based on the results of the descriptive statistical test with a sample $(\mathrm{N})=20$ banking sub-sectors listed on the IDX, the EPS variable shows that from 20 banks, the minimum EPS value is - 485,000, the maximum value is 1,071,510, the average value is 164.1721 , and the standard deviation of 255.7385 . The smaller the standard deviation that is owned, the higher the observational data distribution and has high variability. The PER variable shows that of the 20 banks, the minimum value is -101.9259 , the maximum value is 822.1584 , the average value is 24.56716 , and the standard deviation is 93.99966. The smaller the standard deviation that is owned, the higher the observational data distribution and has high variability. The GCG variable shows that of the 20 banks, the minimum value is 17,508 , the maximum value is 67,701 , the average value is 34,750 , and the standard deviation is 229,017 . The smaller the standard deviation that is owned, the higher the observational data distribution and has high variability. The stock return variable shows that from 20 banks, the minimum value is 67.31687 , the maximum value is 14057.38 , the average value is 2136,662 , and the standard deviation is 3065.551 . The smaller the standard deviation that is owned, the higher the distribution of observation data and high variability.

Multiple Linear Regression Analysis Test Results

Table 2

Coefficients

\begin{tabular}{|c|c|c|c|c|}
\hline \multirow[b]{2}{*}{ Model } & \multicolumn{2}{|c|}{$\begin{array}{l}\text { Unstandardized } \\
\text { Coefficients }\end{array}$} & & $\begin{array}{l}\text { Standardized } \\
\text { Coefficients }\end{array}$ \\
\hline & & $\mathrm{B}$ & Std. Error & Beta \\
\hline \multirow[t]{3}{*}{1} & (Constant) & .085 & .065 & \\
\hline & Earning Per Share (EPS) & .720 & .099 & .694 \\
\hline & Price Earning Ratio (PER) & .229 & 104 & .211 \\
\hline
\end{tabular}

Dependent Variable: stock return

$$
\mathrm{Y}=0.085+0.720 \mathrm{X} 1+0.299 \mathrm{X} 2+\mathrm{e}
$$

Constant (a) of 0.085, this figure means that without an increase (Earning Per Share and Price Earning Ratio 0 units), the Stock Return will remain at 0.085. This equation also shows the regression coefficient (b1), which results obtained of 0.720 this figure means that if Earning Per Share increases by 1 unit, then the Stock Return will increase to 0.720 . Furthermore, the regression coefficient value (b2) is obtained; the result is 0.299 . This figure means that if the Price Earning Ratio increases by 1 unit, the Stock Return will increase to 0.299 . Therefore it can be said that the Advertising and Personal Selling variables have an influence and are in the same direction as the positive sign on Stock Return. It means that if Earning Per Share and Price Earning Ratio are increased, the Stock Return will increase and vice versa.

\section{Moderation test}

The independent variable used as a moderator will strengthen or weaken the relationship between the independent and dependent variables. The test uses the Moderated regression Analysis interaction test.

1) Good Corporate Governance (GCG) can moderate the effect of Earning Per Share (EPS) on Stock returns. Determination Coefficient Test (Adjusted R2).

Table 3

Result of Determination Coefficient Test (Adjusted R²) Model Summary

\begin{tabular}{lrrrrr}
\hline Model & R & R Square & $\begin{array}{c}\text { Adjusted R } \\
\text { Square }\end{array}$ & $\begin{array}{r}\text { Std. The error of } \\
\text { the Estimate }\end{array}$ \\
\hline 1 & $.299^{\mathrm{a}}$ & .089 & & .074 & .67381 \\
\hline
\end{tabular}

a. Predictors: (Constant), Interaction 1, EPS

b. Dependent variable: stock return 
The adjusted $\mathrm{R}$ square value of 0.074 shows that $7.4 \%$ of the variable Stock Return (Y) can be explained by the variable Earning Per Share (X1), the interaction of the variable Earning Per Share (EPS) and Good Corporate Governance (GCG) (X1Z) or interaction 1. While other variables outside this research model explain the remaining $92.6 \%$.

\section{Significance Test (F Statistical Test)}

Table 4

Simultaneous Significance Test Results (F)

ANOVA

\begin{tabular}{llcllll}
\hline Model & & Sum of Squares & df & Mean Square & F & Sig. \\
\hline 1 & Regression & 12.938 & 2 & 6.469 & 71.833 & $.007^{\mathrm{a}}$ \\
& Residual & 3.652 & 17 & .038 & & \\
& Total & 16.590 & 19 & & & \\
\hline
\end{tabular}

c. Dependent variable: stock return

d. Preditors: (Constanta) Interaction 1, EPS

This shows that the calculated $F$ value is above 2.87 , which is equal to 71,833 with a significance level smaller than 0.05, which is 0.007 . The regression model was used to predict the relationship between Earning Per Share (EPS) on Stock Returns with Good Corporate Governance (GCG) as a moderating variable (Rodriguez-Fernandez, 2016; Fauver \& Fuerst, 2006).

Significance Test of Individual Parameters (t Statistical Test)

Table 5

Simultaneous Significance Test Results (F)

Coefficients

\begin{tabular}{llcc}
\hline & Model & T & Sig. \\
\hline 1 & Constant & 20.194 & .000 \\
& Earnings Per Share & -.572 & .568 \\
& Interaksi 1 & 2.177 & .031 \\
\hline
\end{tabular}

a. Dependent Variable: stock return

It shows that Earning Per Share, Stock Return, and moderation, namely Good Corporate Governance (GCG) have a significant level of $0.031(<0.05)$. So it can be said that individually Good Corporate Governance $(\mathrm{GCG})$ can be a moderating variable between Earning Per Share and Stock Return.

2) Good Corporate Governance (GCG) can moderate the effect of Price Earnings Ratio (PER) on Stock Returns

Determination Coefficient Test (Adjusted $\left.R^{2}\right)$

Table 6

Results of Determination Coefficient Test (Adjusted $\mathrm{R}^{2}$ )

Model Summary

\begin{tabular}{|c|c|c|c|c|}
\hline Model & $\mathrm{R}$ & R Square & $\begin{array}{l}\text { Adjusted R } \\
\text { Square }\end{array}$ & $\begin{array}{l}\text { Std. The error of } \\
\text { the Estimate }\end{array}$ \\
\hline 1 & $.311^{\mathrm{a}}$ & .097 & .081 & .67098 \\
\hline
\end{tabular}

a. Predictors: (Constant), Interaction 2, PER

b. Dependent variable: stock return 
The adjusted $\mathrm{R}$ square value of 0.081 shows that $8.1 \%$ of the Stock Return (Y) variable can be explained by the Price Earnings Ratio (PER) (X2) variable, the interaction of the Price Earnings Ratio (PER) and Good Corporate Governance (GCG) (X2Z) variables or interaction 2. While other variables outside this research model explain the remaining $91.9 \%$.

Significance Test (Test Statistic F)

Table 7

Simultaneous Significance Test Results (F)

ANOVA

\begin{tabular}{llrrrrr}
\hline Model & & Sum of Squares & Df & Mean Square & F & \multicolumn{1}{c}{ Sig. } \\
\hline 1 & Regression & 5.644 & 2 & 4.219 & 32.267 & $.003^{\mathrm{a}}$ \\
& Residual & 13.876 & 17 & .450 & & \\
& Total & 19.320 & 19 & & & \\
\hline
\end{tabular}

a. Dependent variable: stock return

b. Preditors: (Constanta) Interaksi2, PER

This shows that the calculated $\mathrm{F}$ value is above 2.87 , which is equal to 32,267 with a significance level smaller than 0.05 , which is equal to 0.003 . The regression model was used to predict the relationship between Price Earnings Ratio (PER) on Stock Returns with Good Corporate Governance (GCG) as a moderating variable. Significance Test of Individual Parameters (t Statistical Test).

Table 8

Simultaneous Significance Test Results (F)

Coefficients

\begin{tabular}{llcr}
\hline \multicolumn{1}{c}{ Model } & $\mathrm{t}$ & Sig. \\
\hline 1 & Constant & 11.527 & .000 \\
Price Earning & - & 3.261 & .001 \\
Ratio & & \\
Interaksi 1 & 2.943 & .004 \\
\hline
\end{tabular}

a. Dependent Variable: stock return

It shows that Price Earnings Ratio (PER), Stock Return, and moderation, namely Good Corporate Governance (GCG) have a significance level of $0.004(<0.05)$. So it can be said that individually Good Corporate Governance (GCG) can be a moderating variable between Price Earnings Ratio (PER) and Stock Returns.

\section{Discussion}

Based on these results, it can be concluded that the Earning per Share variable shows that the Earning per Share variable, both partially and simultaneously, has a positive effect on Stock Returns. This study's results align with Hartati \& Gusaptono (2010) theory, which states that Earnings per Share describes the company's profitability as reflected on each Share. The increase in EPS indicates that the company has succeeded in increasing investors' level of prosperity; this can increase the demand for shares and stock prices, thereby increasing stock returns (Grey et al., 2013; Pennington \& Tuttle, 2009). The study results are in line with the results of research conducted by Mufti (2015), which states that EPS affects stock returns. Price Earnings Ratio (PER) reflects the company's profit growth. The test results on the Price Earnings Ratio (PER) variable show that the Stock Return variable, both partially and simultaneously, has a positive effect on Stock Returns. This study's results are reinforced by Mahmud and Halim's theory, which states that the Price Earnings Ratio (PER) is an expectation of stock value in the future so that a stock of a company with favorable performance and business prospects will have a high PER value. The results are in line with Putri \& Sujana (2018). It shows that profitability, leverage, and PER have a positive and significant effect simultaneously on Stock returns $t$ as well as the research results of Choiruddin (2015); Lestari 
(2014), which show that Current Ratio, Return On Equity, Debt To Equity Ratio and Price Earnings Ratio have a significant effect on stock returns.

Good Corporate Governance (GCG) can be a moderating variable between Earning Per Share and Stock Return. The research results are in line with Hartati \& Gusaptono (2010), which states that companies that have good EPS and implement GCG will be able to increase investor confidence in issuers and will always be accompanied by a demand for shares of issuers. If the demand for shares increases, the stock price will also increase, then the stock return will increase. This study's results are in line with Mufti's (2015) research, which states that GCG can moderate EPS and profitability on stock returns. From the explanation above, the authors assume that the better corporate governance, the higher the level of investor confidence so that more investors are interested in company shares.

Good Corporate Governance (GCG) can be a moderating variable between Price Earnings Ratio (PER) and Stock Return. The study results are in line with Prihadi (2019) which states that if a company has a low PER and does not implement GCG, it will reduce investors' interest in investing in the company. The demand for shares falls, and the stock price falls, then the stock return will decrease. The results differ from the research results by Choiruddin (2015), which states that GCG does not moderate CR, ROE, and PER on stock returns. GCG is only able to moderate the effect of GCG on stock returns. The same thing is found from the results of Purnamaningsih \& Wirawati (2014) research, which shows that the moderation regression analysis results show that GCG is not a moderating variable for the effect of PER on stock returns.

\section{Conclusion}

Based on the conclusions and discussion results, it can be concluded that Earnings Per Share and Price Earnings Ratio have an influence on stock returns in the banking sector, and Good Corporate Governance can moderate Earnings Per Share and Price Earnings Ratio on stock returns.

\section{Acknowledgments}

This work was collaborative and supported by the Research Funding from the department where we work from. Apart from the funding, we are thankful to all co-authors who were actively participating from beginning to completion of this paper entitled "Market Performance and Corporate Governance in the Banking Sector in Indonesia Stock Exchange.

\section{References}

Arista, D., \& Astohar, A. (2012). Analisis Faktor-Faktor Yang Mempengaruhi Return Saham. Jurnal Ilmu Manajemen dan Akuntansi Terapan (JIMAT), 3(1).

Aronow, W. S., Fleg, J. L., Pepine, C. J., Artinian, N. T., Bakris, G., Brown, A. S., ... \& Harrington, R. A. (2011). ACCF/AHA 2011 expert consensus document on hypertension in the elderly: a report of the American College of Cardiology Foundation Task Force on Clinical Expert Consensus Documents. Circulation, 123(21), 2434-2506.

Choiruddin, C. (2015). Analisis Faktor-Faktor Yang Mempengaruhi Ketepatan Waktu Pelaporan Keuangan. Jurnal ACSY: Jurnal Accounting Politeknik Sekayu, 2(1), 41-56.

Farkhan, F., \& Ika, I. (2012). Pengaruh Rasio Keuangan Terhadap Return Saham Perusahaan Manufaktur Di Bursa Efek Indonesia (Studi Kasus Pada Perusahaan Manufaktur Sektor Food And Beverage). Value Added: Majalah Ekonomi dan Bisnis, 9(1), 22860.

Fauver, L., \& Fuerst, M. E. (2006). Does good corporate governance include employee representation? Evidence from German corporate boards. Journal of financial economics, 82(3), 673-710. https://doi.org/10.1016/j.jfineco.2005.10.005

Grey, C., Stathopoulos, K., \& Walker, M. (2013). The impact of executive pay on the disclosure of alternative earnings per share figures. International Review of Financial Analysis, 29, 227-236. https://doi.org/10.1016/j.irfa.2012.09.005

Hadianto, B., \& Wijaya, M. S. V. (2010). Prediksi Kebijakan Utang, Profitabilitas, Likuiditas, Ukuran, Dan Status Perusahaan Terhadap Kemungkinann Penentuan Peringkat Obligasi: Studi Empirik Pada Perusahaan Yang Menerbitkan Obligasi Di Bursa Efek Indonesia. Jurnal Manajemen Teori dan Terapan| Journal of Theory and Applied Management, 3(3). 
Hartati, M. A. S., \& Gusaptono, H. (2010). The role of life skills training on self-efficacy, self esteem, life interest, and role behavior for unemployed youth. Global Journal of Management and Business Research, 10(1).

Houmes, R., \& Chira, I. (2015). The effect of ownership structure on the price earnings ratio-returns anomaly. International Review of Financial Analysis, 37, 140-147. https://doi.org/10.1016/j.irfa.2014.11.017

Lestari, Y. (2014). Analisa Faktor-Faktor Yang Mempengaruhi Ketepatan Waktu Pelaporan Keuangan Pada Perusahaan Manufaktur Yang Terdaftar Di Bursa Efek Indonesia Tahun 2009-2011 (Doctoral dissertation, Universitas Muhammadiyah Surakarta).

Mufti, C. (2015). Pengaruh Good Corporate Governance (Gcg), Dan Rasio Profitabilitas Terhadap Return Saham Pada Perusahaan Go-Public Non-Perbankan Yang Mengikuti Survey The Indonesian Institute For Corporate Governance Periode 2012-2014 (Doctoral dissertation, Universitas Widyatama).

Pennington, R., \& Tuttle, B. (2009). Managing impressions using distorted graphs of income and earnings per share: The role of memory. International Journal of Accounting Information Systems, 10(1), 25-45. https://doi.org/10.1016/j.accinf.2008.10.001

Pratomo, E. P. (2001). Reksa dana: solusi perencanaan investasi di era modern. Gramedia Pustaka Utama.

Prihadi, T. (2019). Analisis Laporan Keuangan. Gramedia Pustaka Utama.

Purnamaningsih, D., \& Wirawati, N. G. P. (2014). Pengaruh Return on Asset, Struktur Modal, Price to Book Value dan Good Corporate Governance pada Return Saham. E-Jurnal Akuntansi Universitas Udayana, 9(2014), 1-16.

Putri, Y. K. W., \& Sujana, I. K. (2018). The influence of bid-ask spread and leverage on earnings management with good corporate governance as moderating variable. International research journal of management, IT and social sciences, 5(3), 8-21.

Rahman, M. L., \& Shamsuddin, A. (2019). Investor sentiment and the price-earnings ratio in the G7 stock markets. Pacific-Basin Finance Journal, 55, 46-62. https://doi.org/10.1016/j.pacfin.2019.03.003

Rodriguez-Fernandez, M. (2016). Social responsibility and financial performance: The role of good corporate governance. BRQ Business Research Quarterly, 19(2), 137-151. https://doi.org/10.1016/j.brq.2015.08.001

Sang, G. M., Xu, L., de Vrieze, P. T., Bai, Y., \& Pan, F. (2020). Predictive maintenance in Industry 4.0.

Yamato, Y., Fukumoto, Y., \& Kumazaki, H. (2017). Predictive maintenance platform with sound stream analysis in edges. Journal of Information processing, 25, 317-320. 